\title{
Pricing and Its Effects on Market Share of Security Firms in Kenya
}

\author{
David Mwangi Kungu ${ }^{1}$, Kisilu Kitainge ${ }^{2}$, Jacob Omache ${ }^{3}$ \\ ${ }^{1}$ Department of Development studies, School of Human Resource Development, Moi University, Eldoret, Kenya \\ ${ }^{2}$ Technology Education Department, School of Education, University of Eldoret, Eldoret, Kenya \\ ${ }^{3}$ G4S Security Services Ltd, Nakuru Branch, Nakuru, Kenya
}

\section{Email address:}

swmwangi2006@yahoo.com (D. M. Kungu), kitainge@yahoo.com (K. Kitainge), omachej@yahoo.com (J. Omache)

\section{To cite this article:}

David Mwangi Kungu, Kisilu Kitainge, Jacob Omache. Pricing and Its Effects on Market Share of Security Firms in Kenya. Science Journal of Business and Management. Vol. 3, No. 3, 2015, pp. 65-70. doi: 10.11648/j.sjbm.20150303.11

\begin{abstract}
The pricing of any product in the market is an important determinant of the extent to which customers and competitors respond to it. It is also expected that market share of a company's products may be determined by the pricing strategies adopted and implemented. The purpose of this study was therefore to evaluate the effects of pricing on market share of security firms in Kenya, with reference to Nakuru Municipality. The study employed cross-sectional survey method. The target population was 2,500 respondents comprising of customers to security firms. From the target population, a sample of 300 (12\%) respondents was picked; using stratified sampling and simple random sampling techniques. The data were collected using structured questionnaires and analyzed using percentages and frequencies and presented in form of tables and charts. The study found out that price had a bearing on the market share of security firms since customers assessed the utility they got from the product/service based on benefits received and sacrifices made. Therefore, if consumers perceived price to be high, they could purchase competitive brands or substitute products/services leading to a loss of sales (market share). The study recommends that clear pricing structure/policy that takes into consideration a number of factors should be developed to harmonize the customer perception about service quality and the firm's anticipated profitability level.
\end{abstract}

Keywords: Market Share, Price, Pricing Strategies, Flexibility

\section{Introduction}

Security firms are increasingly getting concerned about the changes in their market share for they recognize that when customers are not satisfied they may move to firms that meet their expectations. Market share is a critical factor that has evoked considerable interest for researchers and scholars (Mohar, 2001)15. In addition, organizations have a desired level of demand for products. At any time, there may be no demand, adequate demand, irregular demand or too much demand, marketing management must find a way of dealing with this different demand (Kotler, 1988)12. According to (Perreault \& McCarthy 1996)22 a market is a group of potential customers with similar needs who are willing to exchange value with sellers offering various goods and/or services. It is on this foundation that this study aims at analyzing how price may affect the market and consequently market share for the different products offered by security firms in Kenya.
In the words of (Paul \& Donnelly 2007)20, demand influences pricing decisions, primarily the nature of the target market and expected reactions of consumers to a given price. There are three main considerations; demographic factors, psychological factors and price elasticity. In the initial selection of the target market that a firm intends to serve, a number of demographic factors are considered; number of potential buyers, and their age, education, and gender, location of potential buyers, position of potential buyers, expected consumption rates of potential buyers and economic strength of potential buyers. These factors help determine market potential and are useful to estimating expected sales at various price levels.

Supply influence in pricing decisions can be discussed in relation to three basic factors which relate to the objectives, costs, and the nature of the product. Pricing objectives should be derived from the overall marketing objectives, which in turn should be derived from corporate objectives. However, the profit maximization norm does not provide the operating marketing manager with a single unequivocal guideline for 
selecting price. In addition the marketing manager, does not have perfect cost revenues, and market information to be able to evaluate whether or not this objective is being reached. In practice then, many other objectives are employed as guidelines for pricing decisions (Paul \& Donnelly, 2007)20. Paul \& Donnelly (2007)20 states that although numerous product characteristics can affect pricing, three of the most important are; perishability, distinctiveness and stage in the product life cycle.

Form the literature above, it is clear that a market is a complex structure with many players both domestic and non-domestic thus determining the market share of each company/organization. Price being one of the many factors, therefore, the purpose of this study is to evaluate effects of pricing on market share of security firms in Kenya.

\section{Problem Statement}

Security companies are concerned about situations of competition for their market share globally, regionally and locally. A comparison of market share position in 2009 in relation to 2005 for some security firms indicated that G4S Security services (K) Ltd gained increase in market share by $15 \%$, Patriotic Guards Ltd lost 25\%, B.M Security Ltd gained 5\%, Wells Fargo Ltd gained 2\% and the other smaller firms gained 3\% (KASC, 2009)11. These companies have to continuously realign their strategies with the emerging trends in order to attract new business and achieve their financial objectives (Gosling, 2009)11. Such strategies focus on pricing, market segmentation, new product development and market intelligence. Security firms are increasingly getting concerned about the changes in their market share for they recognize that if customers are not satisfied with services offered, they may move to other firms which meet their expectations. With the changes in market share evident in the security firms in Nakuru, there is need to explore how the security firms are managing these changes and the strategies used to sustain and grow their market share.

\section{Significance of the Study}

The study provides information that financial intermediaries, government institutions, and the security services sector, can use to make appropriate decisions. The financial intermediaries may use the information to finance security firms that perform well in terms of market share. Government institutions may use the information to create an enabling environment to assist security firms build their market share. Finally, the security services sector may use the results to make strategic decisions pertaining to market share and competition.

In addition, the study avails valuable information to researchers interested to do more research in this area of study as the document will be made available in the library for perusal and use by other researchers. The information from the research study may also benefit the general public in understanding the main issues relating to market share of security firms in Kenya.

\section{Research Methodology}

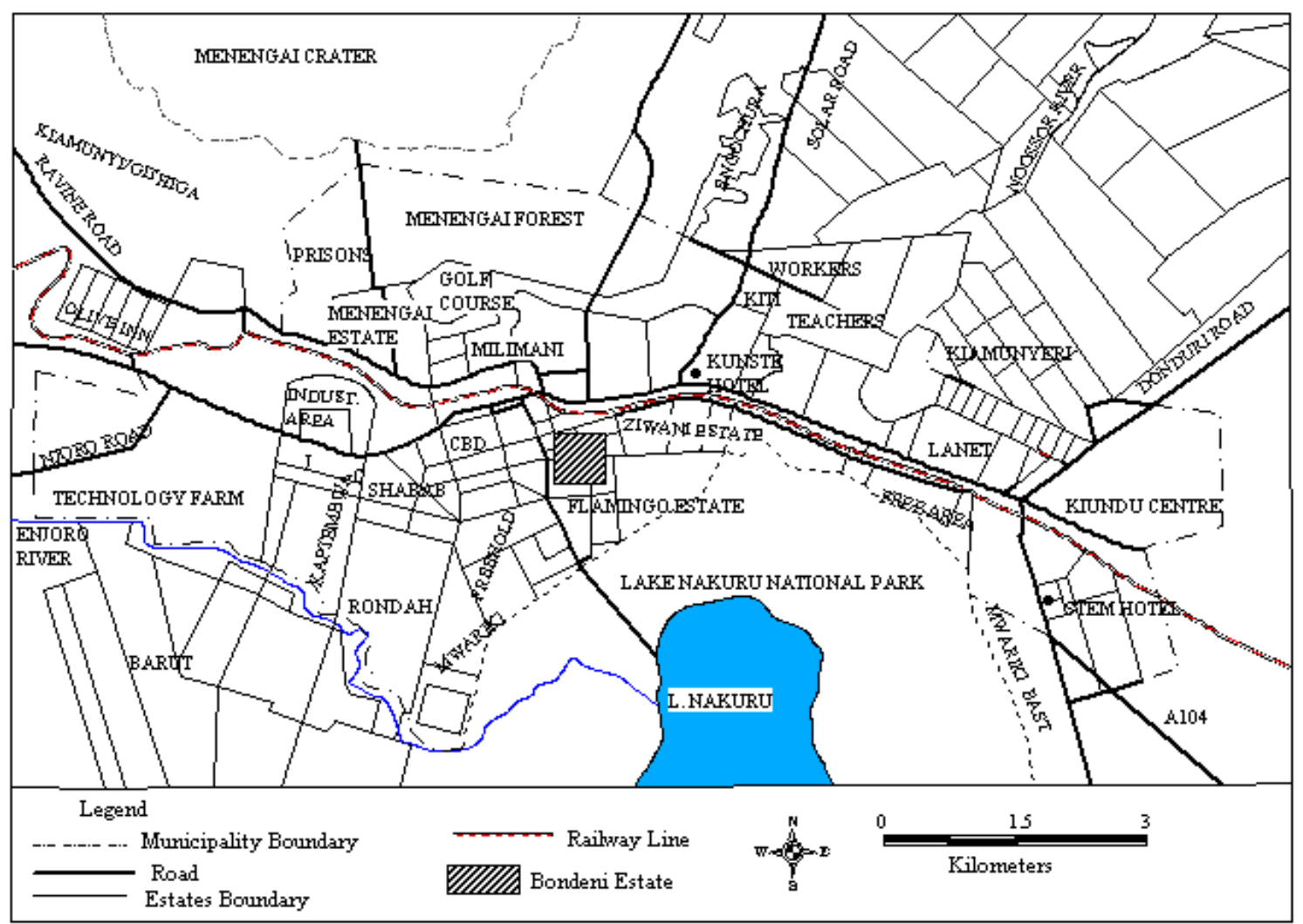

Figure 1. Map of Study Area, Nakuru Municipality. 
The researcher employed a survey research design. The study was carried out in Nakuru Municipality (figure 1) with a population of 2,500 customers drawn from all security firms within the municipality. These firms surveyed were reputable local security firms, international security firms, privately owned and Jua Kali security firms. From the target population, a sample of 300 participants was picked using stratified sampling and simple random sampling techniques. Both structured and open questionnaires and interviews were used to collect data from each respondent. The structured questionnaires from the respondents were analyzed quantitatively. They were checked, edited, coded and keyed in the SPSS computer programme and analysed descriptively using percentages and frequencies and presented in tables, bar charts and pie charts. On the other hand, qualitative data were analyzed using the thematic steps (Creswell 2008)6.

\section{Results and Discussion}

\subsection{Price and its Effects on Market Share}

The study sought to find out the respondents' opinion on various price variables in order to establish effects of pricing on market share of security firms. The results are presented in table 1 .

Table 1. Security firms 'position on effects of pricing on market share.

\begin{tabular}{|c|c|c|c|c|c|c|c|c|c|c|}
\hline \multirow{2}{*}{ Price Variables } & \multicolumn{2}{|c|}{ Strongly Disagree } & \multicolumn{2}{|c|}{ Disagree } & \multicolumn{2}{|c|}{ Neutral } & \multicolumn{2}{|l|}{ Agree } & \multicolumn{2}{|c|}{ Strongly Agree } \\
\hline & Frequency & $(\%)$ & Freq. & $(\%)$ & Freq. & $(\%)$ & Freq. & $(\%)$ & Freq. & $(\%)$ \\
\hline Price charged determines market share & 0 & $0 \%$ & 0 & $0 \%$ & 50 & $19 \%$ & 65 & $24 \%$ & 155 & $57 \%$ \\
\hline Customers compare prices before buying & 0 & $0 \%$ & 0 & $0 \%$ & 45 & $17 \%$ & 135 & $50 \%$ & 90 & $33 \%$ \\
\hline Customers consider affordability & 30 & $11 \%$ & 40 & $15 \%$ & 55 & $20 \%$ & 62 & $23 \%$ & 83 & $31 \%$ \\
\hline
\end{tabular}

\subsection{Price Charged for Services}

As appertains the respondents' position on the price charged by the security firms so as to determine if price charged had implications on the overall objective of the study, the study realized that a majority (57\%) of the respondents strongly agreed that the price charged determined market share, $24 \%$ of the respondents agreed that price charged determined market share, while $19 \%$ of the respondents were neutral on the same. These findings reveal that customers bought competitive brands or substitute products/services if the price charged by the current security firm were high. This led to reduced sales which ultimately affected their market share.

\subsection{Price Comparison}

The study sought to find out the respondents' position on price comparison among competitive security firms so as to establish if comparison of prices of various security service providers before buying had implications on the market share of security firms. The study found out that a majority $(50 \%)$ of the respondents agreed, $33 \%$ strongly agreed while $17 \%$ of the respondents were neutral to the fact that most customers compared prices of various security service providers before buying. It is therefore opined that competitive security firms changed prices to attract customers since customers compared prices leading to brand switching. The implication of these findings is that the security firms that constantly compared their price against that of their competitors were able to price correctly in order to keep their clients and attract new ones thus building on their market share.

\subsection{Product Service Affordability}

The study sought to find out the respondents' position on product/service affordability in order to establish if the security firms' product/service affordability had implication. The findings were that $31 \%$ of the respondents strongly agreed, $23 \%$ agreed, $20 \%$ were neutral, $15 \%$ disagreed and a paltry $11 \%$ strongly disagreed to the fact that most customers purchased security products/services that they could afford. It can therefore be opined from these findings are that customers have varying affordability levels for the security products/services. Affordability for security products/services depended on the customers' income, income distribution, buying power, and availability of finances. This implies that affordability of the security firm's products/services should be in line with the customer income, income distribution, buying power and availability of finances for the target market segment(s), since security firms whose products/services were affordable to the customers stood to win more customers thus building on their market share.

\subsection{Price Flexibility}

The study sought to find out the respondents' position on the security firms' flexibility in their pricing structure in order to establish whether flexibility in pricing structure had implication on market share. The findings indicated in figure 2 revealed that $89 \%$ of the respondents agreed while $11 \%$ disagreed to the fact that security firms should be flexible in their pricing structure. It was therefore realized that flexibility in the pricing structure is important and should be undertaken while taking into consideration the product life cycle since a majority of the respondents noted that flexibility in pricing structure affected the market share of security firms because there were different classes of customers with varying purchasing power. This implies that security firms that were flexible in their pricing structure were able to maintain the current customers and attract new ones because customers reacted to price. 


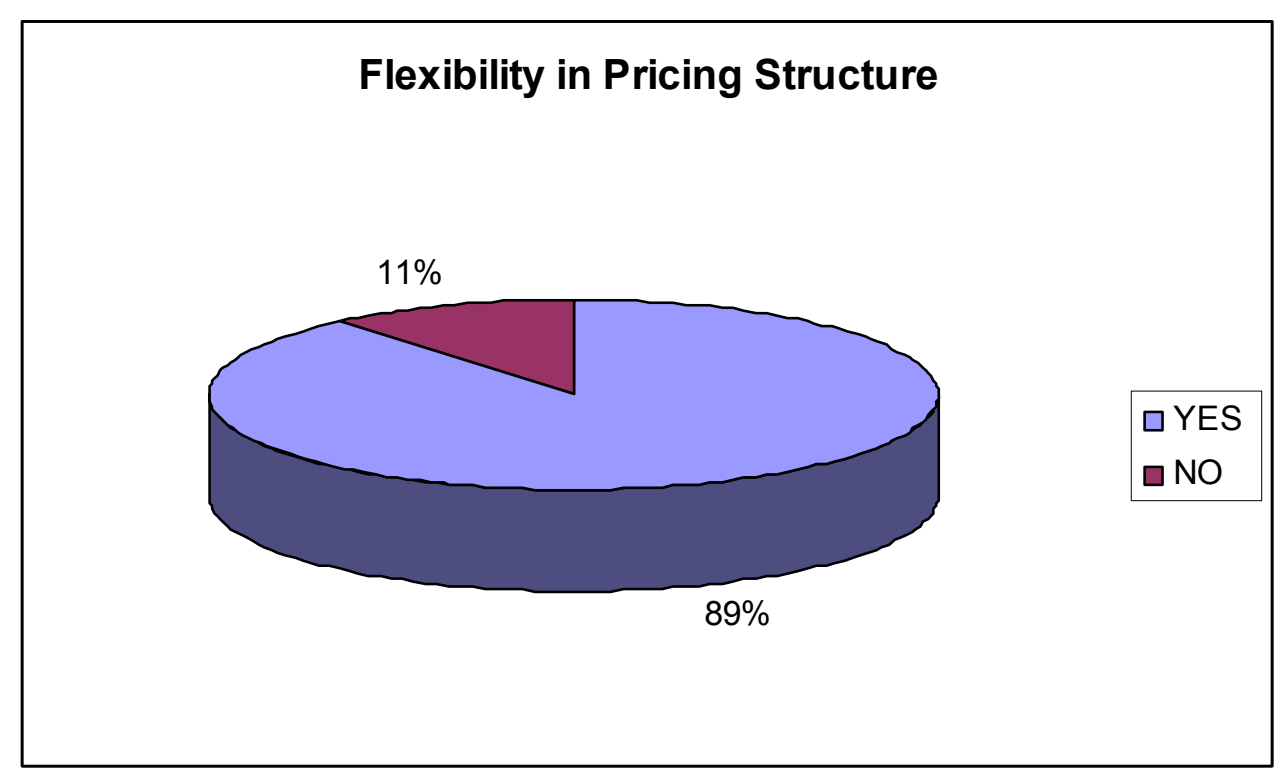

Figure 2. Flexibility of pricing structure.

\subsection{Customers'Satisfaction with Security Firms Pricing}

The study sought to find out the level of satisfaction with the security firms pricing. The results are presented in table 2.

Table 2. Satisfaction level with Security firms' current pricing Structure.

\begin{tabular}{|c|c|c|c|c|c|c|}
\hline \multirow{3}{*}{ Satisfaction Level } & \multicolumn{6}{|c|}{ Price Variables } \\
\hline & \multicolumn{2}{|c|}{ Price Charged } & \multicolumn{2}{|c|}{ Value for Money } & \multicolumn{2}{|c|}{ Price Difference } \\
\hline & Frequency & $(\%)$ & Frequency & $(\%)$ & Frequency & $(\%)$ \\
\hline Extremely Dissatisfied & 0 & $0 \%$ & 0 & $0 \%$ & 0 & $0 \%$ \\
\hline Dissatisfied & 8 & $27 \%$ & 6 & $20 \%$ & 9 & $30 \%$ \\
\hline Neutral & 10 & $33 \%$ & 12 & $40 \%$ & 12 & $40 \%$ \\
\hline Satisfied & 8 & $27 \%$ & 9 & $30 \%$ & 6 & $20 \%$ \\
\hline Extremely Satisfied & 4 & $13 \%$ & 3 & $10 \%$ & 3 & $10 \%$ \\
\hline TOTAL & 30 & $100 \%$ & 30 & $100 \%$ & 30 & $100 \%$ \\
\hline
\end{tabular}

\subsection{Customer Satisfaction with the Price Charged}

The study sought to find out the respondents' satisfaction level with the security firms' current pricing structure. The findings indicated that $33 \%$ of the respondents were neutral as concerns their satisfaction level with the security firms' current pricing structure, $27 \%$ were dissatisfied, $27 \%$ were satisfied, while $13 \%$ of the respondents were extremely satisfied with the security firms' current pricing structure. These findings reveal that customers' perception of fairness in price affected their satisfaction level and that the customers made comparison between their satisfaction and against their investments/losses. This implies that security firms which charged fair prices had more customer loyalty as compared to those that charged unfair or deceptive prices.

\subsection{Value for Money}

The study sought to find out the respondents' satisfaction level with the value that they received for money spent on security services. The study results revealed that $40 \%$ of the respondents were neutral about their satisfaction level on value for money spent on security services, 30\% were dissatisfied, $20 \%$ were satisfied while only $10 \%$ were extremely satisfied. The lessons learnt from the findings are that customers viewed their satisfaction in terms of value for money spent on security services depending on their own anticipation of what they gained or lost for having chosen a particular security firm. The degree to which the service of a particular security firm met the customers' specifications played a key role on how the customers' were satisfied in terms of value for money. This is because customers did not only consider the quality of service but also the price charged for the same. It can therefore be opined that security firms which were able to meet or exceed the customers' expectations, by carefully balancing between quality and fair price, posted a high market share and profitability than those security firms which did not consider a balance between implementing quality and what it cost to do the same (price).

\subsection{Price Difference}

The study sought to find out how comfortable the 
respondents were with the price difference between their current security firms and the existing competitors in order to establish whether the price difference had implication on the overall objective of the study. The findings revealed that $40 \%$ of the respondents were neutral on their satisfaction level with the price difference between their current security firms and the competitors, $30 \%$ were dissatisfied, $20 \%$ were satisfied with the price difference, $10 \%$ were extremely satisfied, while none of the respondents were extremely dissatisfied with the price difference. These implies that customers evaluated price comparatively in reference to what competitors offered rather than in an absolute sense and that customers had a range of acceptable prices and would switch the brand or security firm if price was not acceptable to them. It can therefore be opined that price charged by a security firm reflected its value image in the eyes of customers and competitors and had to be competitive to be acceptable to the customers. The security firms that were competitive in their pricing structure were able to minimize the impact of competition on their business which enabled them to defend their market share.

\subsection{Price Rating}

The study sought to find out the effect of price rating on the market share of security firms. It was realized that a majority of respondents $(40 \%)$ were neutral on the price difference between their security firms and the competitors. The reason given for this was that for highly priced security services, customers believed that services from such firms were quality or prestigious. In addition, $30 \%$ of the respondents were dissatisfied noting that they had many choices and were willing to shop around to receive the best price. The satisfied respondents' $(20 \%)$ noted that they perceived the current price charged by their security firms to be fair in relation to their investment and that of the other individuals. The extremely satisfied (10\%) respondents' noted that they got services that exceeded their expectations at a price they felt was very fair.

\subsection{Brand Switching}

The study sought to find out from the respondents if they would switch from their current security firms if the firms increased the price for their services. The findings as shown in figure 3 were that the majority $(60 \%)$ of the respondents would shift to other brands if the security firms increased their prices, $33 \%$ of the would not shift if the security firms increased their prices, and $7 \%$ were not sure whether they would shift to other brands if the security firms increased the price charged for their services. It can be revealed from the findings that a majority of the security firms' customers were price sensitive and made comparisons just to make the right purchase and get a good deal. Those customers who did not switch had favorable past experience, especially on the quality of service offered by their respective security firms, which made them to insist on the brands. This means that price increase influenced brand switching and the security firms that evaluated the impact of their price change on the industry sales and took the necessary measures, were able to lock their customers in and defended their market share as compared to those firms that were non responsive to customers' brand switching due to price increase.

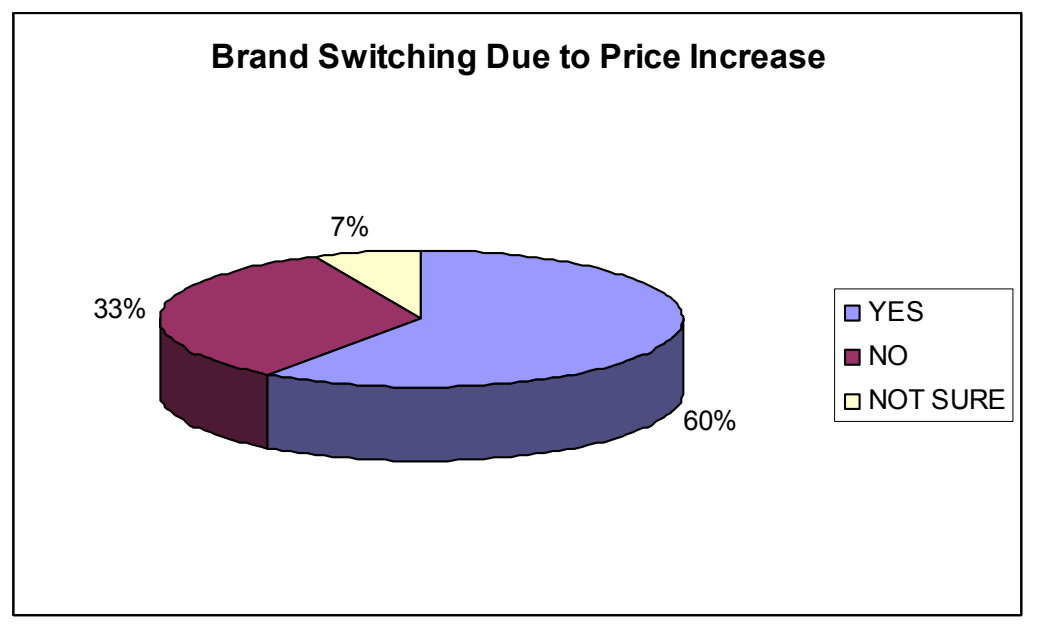

Figure 3. Respondents 'position on Brand Switching due to Price Increase.

\section{Conclusions}

It is clear from the study findings that price has a bearing on the market share of security firms. Price determines market share of security firms in a number of ways. First, customers assess the utility they get from the product/service based on benefits received and sacrifices made. If consumers or organizational buyers perceive price to be too high, they may purchase competitive brands or substitute services leading to a loss of sales (market share). Second, price depend on innovativeness of the product/service, market-penetration strategy, psychology, geographical location of the firm, excess capacity, falling market share, drive to dominate market, increase in costs among others. Therefore, unless a security firm understands its objective of setting a price for its product/service, it risks failing in meeting its long term objective. To increase market share, therefore, a security firm should price its products/services in line with the prevailing 
market circumstances. Third, price affects profitability. Security firms that price too low risk operating at a loss. Security firms should avoid pricing that is too cost-oriented, pricing that is not revised often to reflect market changes, and pricing that does not take into consideration other marketing mix variables. Pricing should therefore, be varied enough for different products/services and market segments.

\section{Recommendations}

While deciding on the price to be charged for products/services, security firms need to bear in mind that customers are price sensitive. Clear pricing structure/policy that takes into consideration a number of factors should be developed to harmonize the customer perception about service quality and the firm's anticipated profitability level. It does not make sense to price a product/service too highly and end up loosing customers. Security firms in Kenya should endeavor to understand the increasing challenges facing the security industry, as this would create a better understanding of the market and accordingly develop pricing structures that are tailor-made to address the different needs of their customers. The Kenyan economy for instance, has been struggling since late 2007, as a result of post election violence coupled with the global financial crunch. As such, pricing should take into consideration such socio-economic factors.

In addition, it is necessary for the security firms to explore other forms of satisfying their customers apart from price, for instance by developing new products/services that can satisfy the changing customer needs. Other avenues that can be explored include strategic alliance and outsourcing among the security firms which can avail an opportunity for cost cutting. Whichever option the security firms decide to employ to streamline their pricing structure, it is extremely important to consider the fact that price must change with the changing trends in the market. The price charged must reflect the reality of the market in terms of competition, buying power of the customers and industry regulation.

\section{References}

[1] Arnould, E., Price L., \& Zinkhan, G. (2004). Consumers. McGraw Hill, U.S.A.

[2] Baker, J.M. (2000). Marketing Strategy \& Management Palgrave Macmillan: U.S.A

[3] Berkowitz, N., Kerin, A., \& Rudelius, W. (1989). Marketing. Richard D. Irwin: Homewood, U. S.

[4] Bingham, G.F Jr., Gomes, R., \& Knowles A.P. (2005). Business Marketing. McGraw Hill/Irwin: U.S.A
[5] Churchill, G. A Jr. G. (1991). Marketing Research, Methodology Foundations. Dryden Press: Fort Worth

[6] Creswell, J.W. (2008). Research Design: Quantitative, Qualitative Research and Mixed Research Approaches (3rded.). Thousands Oak, CA: Sage.

[7] Gosling, M (2008). Amor Group: making the World Safer. G4S International Journal 4-6.

[8] Hutt, D.M., \& Speh, W.T. (2007). Business Marketing Management: B2B.Thomson Higher Education: U.S.A.

[9] Jobber, D. (2007). Principles and Practices of Marketing Mc Graw-Hill: London, U.K

[10] Kerin, A., Berkowitz, N., Hartley, W. \& Rudelius, W.(2003). Marketing McGraw-Hill: New York. U.S.A

[11] Kenya Association of Security Companies-KASC (2009), Performance of Security Companies, Annual news letter, Unity Press. Nairobi

[12] Kotler, P. (1988). Marketing Management Prentice Hall: New Delhi, India.

[13] Kotler, P. \& Amstrong, G. (1994). Principles of Marketing. Prentice Hall: New Delhi, India.

[14] Kotler, P., Fahey, L., and Jatusripitak, B (1985). The New Competition. Prentice Hall: New Delhi, India.

[15] Mohar, J. (2001). Marketing of High Technology Products and Innovations. McGraw Hill, New York.

[16] Monroe, B.K., \& Cox, J.L. (2001). Pricing Practices That Endanger Profits. Marketing Management Journal, Sept. /Oct. 2001 pp. $42-46$

[17] Mugenda, O.M., \& Mugenda, G.A. (2003).Research Methods. ACTS Press: Nairobi.

[18] Mwathi, G.R (2009).Always be prepared for the Worst. Management Journal of Kenya Institute of Management 20-23.

[19] Oliver, L.R (1973). Behavioral Perspective on Consumers. McGraw Hill, New York

[20] Paul, J.P., \& Donnelly J. (2007). Marketing Management: Knowledge and Skills. McGraw Hill/Irwin: U.S.A.

[21] Pearce II \& J.A Robinson, Jr. R.B. (1991). Strategic Management. Richard D. Irwin: Homewood, U.S.A

[22] Perreault, D.W. Jr., \& McCarthy, E.J. (1996). Basic Marketing: A Global Managerial- Approach McGraw Hill, U.S.A.

[23] Saxena, R. (2006). Marketing Management McGraw Hill, New Delhi, India

[24] Terpstra, V., \& Sarathy, R. (1991). International Marketing Dryden Press: Fort Worth. 